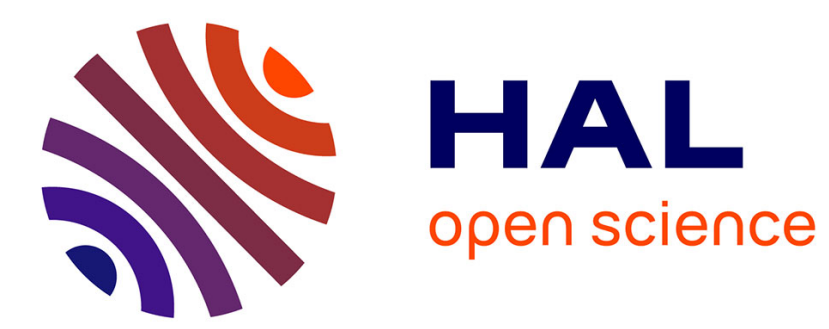

\title{
Sacred barriers to conflict resolution
}

Scott Atran, Robert Axelrod, Richard Davis

\section{To cite this version:}

Scott Atran, Robert Axelrod, Richard Davis. Sacred barriers to conflict resolution. Science, 2007, 317, pp.1039-1040. ijn_00505181

\section{HAL Id: ijn_00505181 \\ https://hal.science/ijn_00505181}

Submitted on 22 Jul 2010

HAL is a multi-disciplinary open access archive for the deposit and dissemination of scientific research documents, whether they are published or not. The documents may come from teaching and research institutions in France or abroad, or from public or private research centers.
L'archive ouverte pluridisciplinaire HAL, est destinée au dépôt et à la diffusion de documents scientifiques de niveau recherche, publiés ou non, émanant des établissements d'enseignement et de recherche français ou étrangers, des laboratoires publics ou privés. 


\section{Sacred Barriers to Conflict Resolution}

Resolution of quarrels arising from conflicting sacred values, as in the Middle East, may require concessions that acknowledge the opposition's core concerns.

\section{Scott Atran, ${ }^{1}$ Robert Axelrod, ${ }^{2}$ Richard Davis ${ }^{3}$}

$\mathrm{E}$ fforts to resolve political conflicts or to counter political violence often assume that adversaries make rational choices (1). Ever since the end of the Second World War, "rational actor" models have dominated strategic thinking at all levels of government policy (2) and military planning (3). In the confrontations between nation states, and especially during the Cold War, these models were arguably useful in anticipating an array of challenges and in stabilizing world peace enough to prevent nuclear war. Now, however, we are witnessing "devoted actors" such as suicide terrorists (4), who are willing to make extreme sacrifices that are independent of, or all out of proportion to, likely prospects of success. Nowhere is this issue more pressing than in the Israeli-Palestinian dispute (5). The reality of extreme behaviors and intractability of political conflicts there and discord elsewhere-in the Balkans, Kashmir, Sri Lanka, and beyond - warrant research into the nature and depth of commitment to sacred values.

\section{Sacred Values}

Sacred values differ from material or instrumental ones by incorporating moral beliefs that drive action in ways dissociated from prospects for success. Across the world, people believe that devotion to core values (such as the welfare of their family and country or their commitment to religion, honor, and justice) is, or ought to be, absolute and inviolable. Such values outweigh other values, particularly economic ones (6).

To say that sacred values are protected from trade-offs with economic values does not mean that they are immune from all material considerations. Devotion to some core values, such as children's well-being (7) or the good of the community (8), or even to a sense of fairness (9), may represent universal responses to long-term evolutionary strategies

${ }^{1}$ CNRS-Institut Jean Nicod, 29 rue d'Ulm, 75005 Paris, France; University of Michigan, Ann Arbor, Ml; and John Jay College of Criminal Justice, New York, NY, USA; e-mail: satran@umich.edu. 2University of Michigan, Ann Arbor, MI 48109, USA; e-mail: axe@umich.edu. ${ }^{3}$ RTI International, 3040 Cornwallis Road, Research Triangle Park, NC 27709, and ARTIS Research and Risk Modeling, Washington, DC, USA; e-mail: richdavis@rti.org.

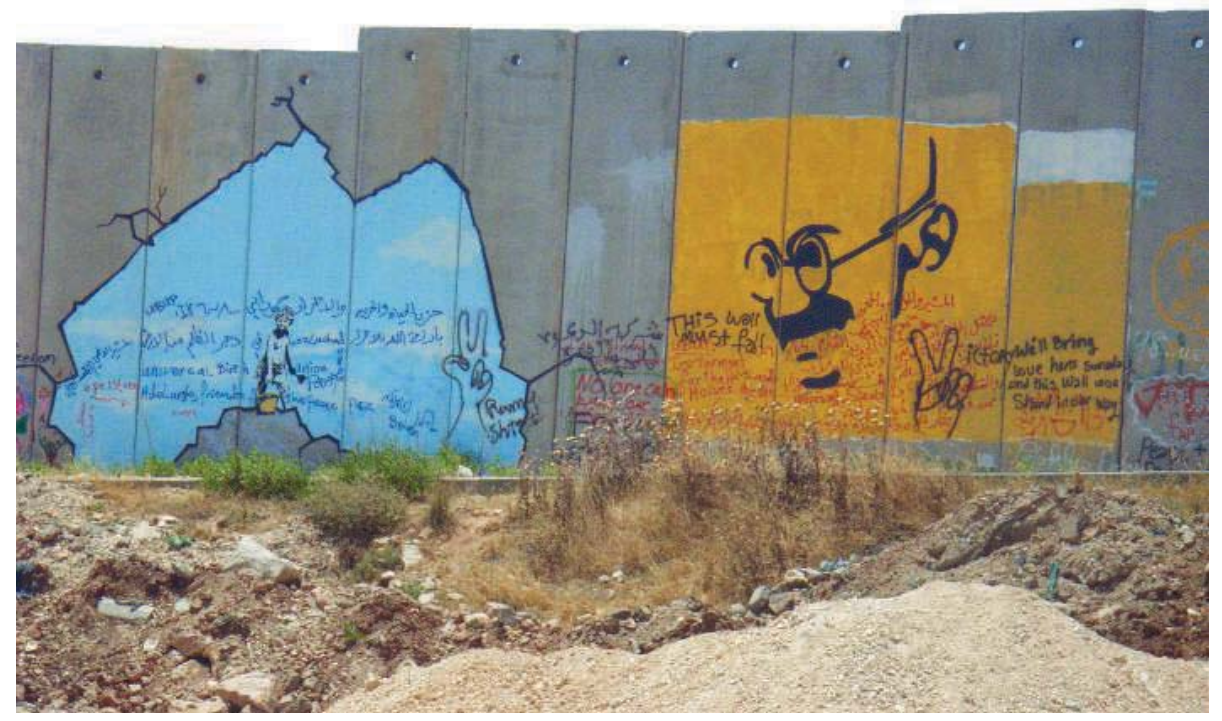

The Spirit of Mahatma Gandhi, for whom "values become your destiny," on the wall at the Kalandiya checkpoint separating the West Bank from Israel.

that go beyond short-term individual calculations of self-interest, yet advance individual interests in the aggregate and long run. Other such values are clearly specific to particular societies and historical contingencies, such as the sacred status of cows in Hindu culture or the sacred status of Jerusalem in Judaism, Christianity, and Islam. Sometimes, as with cows (10) or forests (11), the sacred may represent accumulated material wisdom of generations in resisting individual urges to gain an immediate advantage of meat or firewood for the long-term benefits of renewable sources of energy and sustenance. Political leaders often appeal to sacred values as a way of reducing "transaction costs" (12) in mobilizing their constituents to action and as a least-cost method of enforcing their policy goals (13).

Matters of principle or "sacred honor," when enforced to a degree far out of proportion to any individual or immediate material payoff, are often seen as defining "who we are.” After the end of the Vietnam War, successive U.S. administrations resisted Hanoi's efforts at reconciliation until Hanoi accounted for the fate of U.S. soldiers missing in action (14). Granted, the issue was initially entwined with rational considerations of balance of power at the policy-making level: The United States did not want to get too close to Hanoi and so annoy Beijing (a more powerful strategic ally against the Soviet Union). But popular support for the administration's position, especially among veterans, was a heartfelt concern for "our boys," regardless of numbers or economic consequences.

The "who we are" aspect is often hard for members of different cultures to understand; however, understanding and acknowledging others' values may help to avoid or to resolve the hardest of conflicts. For example, at the peaceful implementation of the occupation of Japan in 1945, the American government realized that preserving, and even signaling respect for, the emperor might lessen the likelihood that Japanese would fight to the death to save him (15).

\section{Symbolic Concessions}

Our research team has measured emotional outrage and propensity for violence in response to peace deals involving compromises over issues integral to the IsraeliPalestinian conflict with Israeli settlers, Palestinian refugees, and Hamas versus nonHamas students. Our proposed compromises were exchanging land for peace, sovereignty over Jerusalem, the right of Palestinian refugees to return to their former lands and homes inside Israel, and recognition of the validity of the adversary's own sacred values (1). We found that the use of material incen- 
tives to promote the peaceful resolution of political and cultural conflicts may backfire when adversaries treat contested issues as sacred values. Symbolic concessions of no apparent material benefit may be key in helping to solve seemingly intractable conflicts.

These results correspond to the historical sense of experts. One senior member of the National Security Council responded recently (16), "This seems right. On the settlers [who were to be removed from Gaza], Sharon realized too late that he shouldn't have berated them about wasting Israel's money and endangering soldiers' lives. Sharon told me that he realized now that he should have made a symbolic concession and called them Zionist heroes making yet another sacrifice."

As further illustration that sacred values can be at the heart of deep-seated political disputes, Isaac Ben Israel, a former Israeli Air Force general who currently heads his country's space agency, told us: "Israel recognizes that the [Hamas-led] Palestinian government is still completely focused on what it considers to be its essential principles. ... For Hamas, a refusal to utter the simple words 'We recognize Israel's right to exist' is clearly an essential part of their core values. Why else would they suffer the international boycott ... and let their own government workers go without pay, their people go hungry, and their leaders risk assassination?" Ghazi Hamad, a Hamas leader and then-spokesman for the Palestinian government, told us: "In principle, we have no problem with a Palestinian state encompassing all of our lands within the 1967 borders. But let Israel apologize for our tragedy in 1948, and then we can talk about negotiating over our right of return to historic Palestine." In rational-choice models of decisionmaking, something as intangible as an apology could not stand in the way of peace.

Apologies may not be so much deal-makers in themselves as facilitators for political compromise that may also involve material transactions. At its founding in 1948, Israel was in dire economic straits (17). But Israel and the World Jewish Congress refused to demand compensation directly from Germany for the property of murdered European Jews. Israel insisted that before any money could be considered, Germany must publicly declare contrition for the murder and suffering of Jews at German hands.

An Iranian scholar and former top diplomat remarked recently that "symbolic statements are important if sincere, [and] without reservation. In 2000, [then-Secretary of State Madeleine] Albright seemed to apologize to Iran for past offenses but then said [in a memorandum] 'despite the trend towards democracy, control over the military, judiciary, courts and police remain in unelected hands.' Our leadership interpreted this as a call for a coup" (18).

\section{Recent Discussions}

We went to the Middle East in February 2007 to directly probe issues of material trade-offs and symbolic concessions with leaders of the major parties to the Israel-Palestine dispute. We asked 14 interviewees in Syria, Palestine, and Israel to verify statements for citation. No off-the-record statements contradicted these.

Responses were consistent with our previous findings (1), with one important difference. Previously, people with sacred values had responded "No" to the proposed trade-off; "No" accompanied by emotional outrage and increased support for violence to the trade-off coupled with a substantial and credible material incentive; and "Yes, perhaps" to trade-offs that also involve symbolic concessions (of no material benefit) from the other side. Leaders responded in the same way, except that the symbolic concession was not enough in itself, but only a necessary condition to opening serious negotiations involving material issues as well. For example, Musa Abu Marzouk (former chairman, and current deputy chairman, of Hamas) said "No" to a trade-off for peace without granting a right of return; a more emphatic "No, we do not sell ourselves for any amount," when given a trade-off with a substantial material incentive (credible offering of substantial U.S. aid for the rebuilding of Palestinian infrastructure); but "Yes, an apology is important, but only as a beginning. It's not enough, because our houses and land were taken away from us and something has to be done about that."

Similarly, Binyamin Netanyahu (former Israeli prime minister and current opposition leader in parliament) responded to our question, "Would you seriously consider accepting a two-state solution following the 1967 borders if all major Palestinian factions, including Hamas, were to recognize the right of the Jewish people to an independent state in the region?" with the answer: "Yes, but the Palestinians would have to show that they sincerely mean it, change their textbooks and anti-Semitic characterizations and then allow some border adjustments so that Ben Gurion [Airport] would be out of range of shoulderfired missiles."

For Israel's former chief hostage negotiator, Ariel Merari, “Trusting the adversary's intentions is critical to negotiations, which have no chance unless both sides believe the other's willingness to recognize its existential concerns." Indeed, recognition of some "existential values" may change other values into material concerns, e.g., "since the PLO's [Palestine Liberation Organization's] recognition of Israel, most Israelis no longer see rule over the West Bank as existential" (19).

We urgently need more scientific research to inform better policy choices. Our findings about sacred values suggest that there may be fewer differences than are publicly acknowledged in the material trade-offs that "moderate" and "radical" leaders in Palestine, Israel, and elsewhere may be willing to make. Overcoming moral barriers to symbolic concessions and their emotional underpinnings may pose more of a challenge but also offer greater opportunities for breakthroughs to peace than hitherto realized.

\section{References and Notes}

1. J. Ginges, S. Atran, D. Medin, K. Shikaki, Proc. Natl. Acad. Sci. U.S.A. 104, 7357 (2007).

2. ]. Gaddis, Strategies of Containment: A Critical Appraisal of Postwar National Security (Oxford Univ. Press, New York, 1995).

3. G. Allison, Essence of Decision: Explaining the Cuban Missile Crisis (Longman, New York, 1999).

4. S. Atran, Science 299, 1534 (2003).

5. "America's image slips, but allies share U.S. concerns over Iran, Hamas" (Survey Report, Pew Research Center, 13 June 2006);

http://pewglobal.org/reports/display.php?ReportID=252.

6. P. E. Tetlock, Trends Cogn. Sci. 7, 320 (2003).

7. W. D. Hamilton, J. Theor. Biol. 7, 1 (1964).

8. E. Durkheim, The Elementary Forms of Religious Life (1912) [translated by K. E. Fields] (Free Press, New York, 1995).

9. M. Hauser, Moral Minds: How Nature Designed Our Universal Sense of Right and Wrong (Ecco, New York, 2000).

10. M. Harris, Curr. Anthropol. 7, 51 (1966).

11. S. Atran, D. Medin, N. Ross, Psychol. Rev. 112, 744 (2005).

12. A. Varshney, Perspect. Polit. 1, 85 (2003).

13. R. Goodin, Policy Sci. 12, 131 (1980).

14. O. Babson, "Diplomacy of isolation: United States unilateral sanctions policy and 1975-1995" (WWS case study 4/02, Woodrow Wilson School, Princeton Univ., Princeton, N], 2002); www.wws.princeton.edu/cases/ papers/sanctions.html.

15. J. Dower, Embracing Defeat: Japan in the Wake of World War II (Norton, New York, 1999).

16. The response was given to the final point mentioned in S. Atran, R. Axelrod, R. Davis, Synopsis of briefing to National Security Council staff, The White House, 28 March 2007; www.sitemaker.umich.edu/satran/files/ synopsis_atran-sageman_nsc_brief_28_march_2007.pdf.

17. I. Lustick, J. Int. Aff. 60, 51 (2006).

18. Remarks made at the Fifth Meeting, Permanent Monitoring Panel on Terrorism, World Federation of Scientists, Erice, Italy, 18 May 2007.

19. In May 2007, we broached ideas of mutual symbolic concession. Hamas would renounce Article 32 of its 1988 Covenant, which highlights "Zionist scheming ... laid out in The Protocols of the Elders of Zion," a notorious antiSemitic tract forged by Russian Czarist police. Israel would renounce the slogan, "A land without people for a people without land," coined by Israel Zangwill a century ago to describe Zionist aspirations. Leaders on both sides acknowledge they would be renouncing a falsehood and grant that such statements by the other side could represent a psychological breakthrough. But discussion was halted because of civil strife in Gaza.

20. Supported by the NSF, U.S. Air Force Office of Scientific Research, and Centre National de la Recherche Scientifique. Thanks to D. E. Axelrod, J. Ginges, and D. Medin for suggestions. 